\title{
Violeta Parra y el problema del mal'
}

Violeta Parra and the problem of evil

Violeta Parra e o problema do mal

Lic. Lucy Oporto Valencia

Recibido: 03/06/2014 · Aceptado: 10/09/2014

\author{
(...) HOY VIVIMOS NUESTRA MUERTE. \\ PRONTO MORIREMOS NUESTRA MUERTE... \\ ES LA PATRIA QUE SE DESINTEGRA (...). \\ "Existenciales nocturnos. José Saavedra" en \\ El espíritu de la época $N^{\circ} 10$, Santiago de Chile, \\ septiembre 1988
}

\begin{abstract}
Resumen
El presente ensayo aborda la relevancia filosófica de la obra de la polifacética artista Violeta Parra, en lo concerniente al problema del mal, sus vínculos con la demonología vetero y neotestamentaria, y el "fin de la teodicea". De El gavilán, su obra maestra, inicialmente concebida para ballet y prefiguración del ascenso del fascismo en Chile a partir de 1973, y otras composiciones musicales suyas, como Pupila de águila, Una copla me ha cantado y Cantores que reflexionan, se desprende una concepción histórico-política del mal y lo demoníaco, unida a una alta valoración del arte en cuanto forma de conocimiento y ampliación de la conciencia.
\end{abstract}

Palabras clave: expulsión intelectual - fascismo - fin de la teodiceaproblema del mal - relevancia filosófica

\footnotetext{
1 Versiones abreviadas de este ensayo fueron presentadas en el marco de la Jornada 2013 de Filosofía Chilena, organizada por Grupo Cuatro, realizada el 28 de agosto de 2013, en el Museo Benjamín Vicuña Mackena, Santiago de Chile. Y con ocasión de la presentación de Exterioridad $N^{\circ} 1$, Revista de Filosofía. Proyecto elaborado por estudiantes de la Escuela de Filosofía de la Facultad de Ciencias Religiosas y Filosofía, Universidad Cardenal Silva Henríquez. Alonso Muñoz Letelier y Javier Gatica Vargas, editores. Jueves 24 de abril de 2014, Sede Lo Cañas, La Florida, Región Metropolitana.
} 


\begin{abstract}
This essay addresses the philosophical relevance of the work of the multifaceted artist Violeta Parraconcerning the problem of evil, its links with the Old and New Testaments demonologyand the "end of theodicy." From El gavilán, his masterpiece, originally designed for ballet and foreshadowing the rise of fascism in Chile since 1973, and her other musical compositions, as Pupila de águila, Una copla me ha cantado y Cantores que reflexionan, it is possible to see a historical and political conception of evil and the demonic, together with a high value of arts as a form of knowledge and expansion of consciousness.
\end{abstract}

Key words: intellectual expulsion - fascism - end of theodicy -the problem of evil - philosophic pertinence

\title{
Resumo
}

O presente ensaio aborda a relevância filosófica da obra do artista polifacética Violeta Parra, no que concerne ao problema do mal, seus vínculos com a demonologia vétero e neotestamentário e o "fim da teodicéia". Do Gavião, sua obra-prima, inicialmente concebida para balé e prenúncio da ascensão do fascismo no Chile a partir de 1973 e outras composições musicais, como Pupila de águila, Una copla me ha cantado y Cantores que reflexionan, desprende-se uma concepção histórica e política do mal e do demoníaco, unida a uma estimação elevada da arte, assim como forma de conhecimento e extensão da consciência.

Palavras-chave: Expulsão Intelectual - Fascismo - Fim da Teodicéia - Problema do Mal - Relevância Filosófica

\section{La expulsión intelectual de Violeta en Chile}

Las presentes consideraciones forman parte de un trabajo más vasto, intitulado El Diablo en la música. La muerte del amor en El gavilán, de Violeta Parra, editado en noviembre de 2008 por Altazor, de Viña del Mar, y reeditado en octubre de 2013, en versión corregida y aumentada, por Editorial Universidad de Santiago de Chile. Ellas profundizan aspectos no suficientemente madurados en la época de su primera edición, como la relación entre El gavilán, la demonología, y el problema del mal en el siglo XX, entre otros.

El gavilán y otras composiciones de Violeta Parra (1917-1967), como Pupila de águila o Qué te trae por aquí, referidas a la presencia irradiante 
de aves malignas, o Cantores que reflexionan, acerca del mal que acecha a los cantores y músicos desde dentro, o Una copla me ha cantado, acerca de una música capaz de matar, entre otras, aluden de un modo u otro a estas cuestiones. Ello hace patente la relevancia filosófica de la obra de Violeta en distintas dimensiones, tanto epistemológicas como éticas, metafísicas, teológicas y, desde luego, estéticas.

Relevancia filosófica, o potencial filosófico, es un concepto metafilosófico basado en la concepción argumentativa de la filosofía, perteneciente a la tradición analítica, más tarde purificada y formalizada como pluralismo metafilosófico multidimensional, de M. E. Orellana Benado (1955)². Designa la remisión directa, indirecta o fragmentaria, de obras y documentos no filosóficos en principio, a las distintas concepciones y tradiciones filosóficas que constituyen la historia de las prácticas filosóficas. Pero también a concepciones y tradiciones pertenecientes a otros dominios de prácticas -las que, a su vez, son susceptibles de un examen de su relevancia filosófica-, tales como la psicología, la literatura, el cine, la música, las artes en general, la religión, la política, la economía o las ciencias, entre otros.

El concepto de relevancia filosófica integra la concepción filosófica denominada arqueología del alma. Según ésta, la filosofía consiste en la indagación de diversas matrices, estructuras, tramas, formas, líneas, imágenes, huellas, trasuntos, barruntos, e incluso ruinas de un pensamiento, manifestados o subyacentes como elementos o formaciones inconscientes, o como construcciones ideológicas, en cualesquiera discursos, documentos, objetos, imágenes, acontecimientos y representaciones en general. Su objetivo es contribuir a la ampliación de la capacidad de conciencia y de conocimiento, como forma de resistencia frente a la dominación, en su vasta envergadura.

La elucidación de dicha relevancia filosófica se levanta, por un lado, contra la sistemática expulsión intelectual de Violeta en Chile. Ésta se

2 ORELlanA BENADO, M. E. Prójimos lejanos. Ensayos de filosofía en la tradición analítica, Ediciones Universidad Diego Portales, 2011. "Tradiciones y concepciones en filosofía", en Filosofía de la Filosofía, editado por Óscar Nudler, Enciclopedia Iberoamericana de Filosofía, vol. № 31, Trotta, Madrid, 2010. 
muestra, sobre todo, a través del difundido prejuicio que ha reducido a la autora a la caricatura de una campesina ignorante y meramente instintiva (en sentido peyorativo), cuya polifacética y magnífica obra habría surgido casi por azar, sin elaboración, y desde una inconsciencia carente de conocimiento. Por otro lado, se levanta contra los actuales esfuerzos, amparados bajo la égida de la transnacional minera BHP Billiton, uno de los financistas privados de la cultura más influyentes en Chile, de hacer de Violeta y su obra un producto de consumo destinado a la juventud sin memoria, y una extensión más de la industria y sus impostados "bienes culturales de excelencia". En ambos casos, se busca disociar a la autora de su propia obra, haciendo desaparecer tanto su marca histórica como sus connotaciones políticas, con el fin de obstaculizar una reflexión de más vasto alcance y rigor acerca de ellas, sobre todo en el plano filosófico.

Baste tener presente que el primer estudio serio acerca de su obra poética, Violeta Parra: santa de pura greda (1988), de Marjorie Agosin e Inés Dölz-Blackburn, fue escrito por dos académicas residentes en Estados Unidos, especialistas en literatura hispánica, y publicado casi veinte años después de la muerte de Violeta ${ }^{3}$. En Chile, en cambio, la mayor parte de la obra acerca de ella son biografías basadas en el testimonio de terceros, cuya autoridad no es problematizada, ni cuestionada. A partir de aquí, paradójicamente, se hace patente otra variante de los intentos por disociar a Violeta de su obra: la tendencia generalizada, y de sentido común, a reducirla a una correspondencia biunívoca, superficial y facilista, lo cual ha contribuido no poco a fortalecer el prejuicio que ha oscurecido tanto el conocimiento acerca de su obra como su apertura a horizontes más amplios y profundos, en el orden del espíritu.

El gavilán, compuesta a fines de la década de 1950, y concluida en 1964 es, cabalmente, la obra maestra de la autora, debido a la correspondencia entre forma, contenido y significado de ambos. Original-

3 AGOSIN, Marjorie / DÖLZ-BLACKBRUN, Inés. Violeta Parra: santa de pura greda. Un estudio sobre su obra poética, Planeta, Santiago de Chile, 1988. 
mente concebida como ballet, de ella sólo se conservan dos versiones largas, interpretadas por Violeta. Ambas, grabaciones caseras. Una, realizada en Santiago de Chile, alrededor de 1960, por Miguel Letelier (1939). Y la otra en París, en 1964, por Héctor Miranda, director del conjunto Calchakis, conocida como versión París. Existe, además, una versión breve, grabada con ocasión de la entrevista concedida por Violeta a Mario Céspedes (1921-2007), para Radio Universidad de Concepción, en enero de 1960. Y por último, una versión aún inédita grabada por Violeta en casa de Margot Loyola (1918), para que ella la interpretara, cuya datación es imprecisa. El gavilán jamás fue grabada en estudio. El ballet nunca llegó a ser montado. Y Loyola nunca llegó a grabar la pieza interpretada por ella misma. Pero las primeras versiones mencionadas han sido editadas y difundidas públicamente post mortem, tanto en Francia como en Chile, a partir de 1975.

El gavilán narra la historia de una mujer seducida, traicionada y asesinada por un ser masculino, no necesariamente un hombre. El análisis de sus imágenes y estructura formal muestra que aquél es una de las apariencias del Diablo. Esta obra lo presenta como un ave maligna, rapaz y carnívora: un gavilán, símbolo de la perversión del poder del espíritu, prefiguración inconsciente del suicidio de Violeta, y de la era del fascismo y el espíritu fascista en Chile, y cifra de su catástrofe política y espiritual, iniciada con el golpe de Estado de 1973. En un segundo nivel de análisis, conforme a la teoría del chivo expiatorio, de René Girard (1923), El gavilán muestra, por un lado, una persecución seguida de homicidio. Y por otro, la participación de una comunidad, expuesta al peligro de desintegrarse debido a una crisis, en el sacrificio cruento de una víctima no pertinente al Diablo, con el fin de reconstituirse a partir de la descarga de una violencia unánime sobre dicha víctima inocente.

La unidad de esta obra se basa en el uso sistemático y reiterado del tritono, prohibido en la polifonía medieval. Pues se pensaba que, a través de este sonido disonante, entraba el Diablo en la música. De ahí, su designación como diabolus in musica o "el intervalo del Diablo". Violeta lo presenta como elemento formal, estético y simbólico, en relación con la extrema violencia, padecido y provocado, que constituye el relato de El gavilán. 
Ahora bien, esta obra se vincula a otras imágenes de Violeta. En sus Décimas, describe la muerte a través de la imagen del "satanás caníbal", asesino y antropófago, que destruye a los seres:

Llega com' un torbellino sacando chispas del suelo, no ha de escapar de su anhelo ni el que se siente divino. Sus dientes son un molino pa' triturar al mortal, el satanás caníbal que puebla los horizontes, profundidades y montes; la muerte es un animal ${ }^{4}$.

Las poderosas garras del gavilán y los dientes trituradores del satanás caníbal, sitúan las imágenes de Violeta en el horizonte de la demonología vetero y neotestamentaria. Y en este sentido se aproximan, sobre todo, al antecedente de la bestia del Apocalipsis que se desprende de la visión de las cuatro bestias, del profeta Daniel, según Dn 7. Conforme a dicho relato, la primera tiene, entre otros rasgos, alas de águila. La segunda, devora carne. La tercera, tiene alas de ave. Y la cuarta, la más poderosa y terrible, de acuerdo con Dn 7, 7, es descrita así:

Después seguí mirando, en mis visiones nocturnas, y vi una cuarta bestia, terrible, espantosa, extraordinariamente fuerte; tenía enormes dientes de hierro; comía, trituraba, y lo sobrante lo pisoteaba con sus patas. Era diferente de las bestias anteriores y tenía diez cuernos.

El Apocalipsis fue compuesto a fines del siglo I. Varios exégetas coinciden en que las imágenes de la bestia tienen un sentido político. Ésta, como fuerza satánica, designa y encarna al Imperio y los emperadores romanos, lo cual se traduce en una concepción histórico-política del

4 PARRA, Violeta; Décimas. Autobiografía en verso (1970), Sudamericana, Santiago de Chile, 1999. P. 115. 
demonio. En esa época, Domiciano (51-96), emperador entre 81 y 96 d. C, fue el primero en exigir un culto y la instalación de estatuas suyas por todas partes, mientras perseguía a los cristianos. En cuanto al libro del profeta Daniel, éste fue escrito entre 167 y 164 a. C., cuando Israel se hallaba bajo la opresión y el terror del tirano Antíoco IV Epífanes (215-163 a. C.), rey de Siria, de la dinastía helenística de los Seléucidas, entre 175 y 164 a. C., considerado prototipo del enemigo y adversario de Dios. En particular, el Dragón con siete cabezas y diez cuernos de Ap 12 y 13 , se basa en la cuarta bestia de Dn 7, 7. Y el pequeño cuerno de dicha bestia, según Dn 7, 8, se refiere a Antíoco Epífanes ${ }^{5}$.

El gavilán y otros textos de Violeta muestran estas imágenes transfiguradas. Su afinidad con lo que más tarde sería la teología de la liberación, indicada por Jorge Montealegre (1954), permite situar sus textos en el horizonte de una concepción histórico-política del mal y el demonio ${ }^{6}$. Por otro lado, su insistencia en señalar la mentira y buscar la verdad a través de su arte, entroncan El gavilán con Jn 8, 42-44, en que el Diablo es descrito como mentiroso, padre de la mentira y homicida desde el principio.

Éstas y las siguientes consideraciones, en vistas a elucidar la relevancia filosófica del pensamiento y la obra de Violeta, demuestran la injusticia de su expulsión intelectual en Chile. Ella se debe no sólo a la desidia e ignorancia radicalizadas y naturalizadas como humus cultural y espiritual en las décadas de la postdictadura, sino también a la creciente profesionalización de la filosofía. Ésta determina discrecionalmente lo que es legítimo estudiar e investigar, en razón de su obediencia a las leyes del mercado académico, y de su confinamiento a la defensa de intereses endogámicos ajenos al espíritu universitario, cuyo horizonte, muy por el contrario, debiera ser la ampliación de la imaginación y el conocimiento, puesta al servicio del desarrollo moral, intelectual y material del país.

5 Biblia de Jerusalén. Desclée de Brouwer, Bilbao, 1975.

6 MONTEALEGRE, Jorge. Violeta Parra. Instantes fecundos, visiones, retazos de memoria. Editorial Universidad de Santiago de Chile, 2011. 


\section{El problema del mal en el siglo XX}

Por otra parte, El gavilán apunta al problema del mal en el siglo XX. En sus indagaciones relativamente recientes acerca del mismo, desde Kant (1724-1804) hasta Hannah Arendt (1906-1975), Richard Bernstein (1932) tematiza su actualidad y relevancia después de Auschwitz, entendido como paradigma de todos los genocidios del siglo $\mathrm{XX}$, en la época de lo que Emmanuel Lévinas (1906-1995) denomina el fin de la teodicea. Bernstein resume su discusión así:

Los filósofos y los politólogos se sienten mucho más cómodos cuando hablan de la injusticia, de la violación de los derechos humanos, de lo que es inmoral y no ético, que cuando hablan de la maldad. Cuando los teólogos y quienes filosofan sobre religión hablan del "problema del mal", normalmente se refieren a algo muy específico: el problema de cómo reconciliar la aparición del mal con la fe en un Dios omnisciente y benévolo. Incluso este discurso se ha hecho propio de especialistas y profesionales, alejándose de las experiencias de la vida de la gente común. (...) Lo importante del así llamado "problema del mal" no es en realidad caracterizar el mal y sus variedades, sino cómo reconciliar la maldad -más allá de cómo se la describa-con las creencias y convicciones religiosas?.

Kant, quien introduce el término "mal radical" -recogido siglos más tarde por Arendt-, es el primer filósofo que indaga acerca del mal sin recurrir a la teodicea filosófica, aun cuando no se distancie completamente de ésta. Por "mal radical" entiende la propensión a no hacer lo que el deber manda; a desobedecer la ley moral. El término "radical" indica que aquélla tiene sus raíces en la naturaleza humana, en la corrupción de la voluntad ${ }^{8}$. Kant se refiere a la teodicea entendida como conocimiento teórico acerca de Dios. Pero, dado que es impo-

7 BERNSTEIN, Richard. El mal radical. Una indagación filosófica (2002), LILMOD, Buenos Aires, 2005. P. 16.

8 Op. cit., p. 51. 
sible conocer aquello que trasciende las fronteras de la experiencia posible, renuncia a recurrir a ella de modo explícito.

Para Bernstein, la pertinencia del concepto kantiano de mal radical en el siglo XX se muestra a través de la colisión entre su insistencia en la responsabilidad personal, y las tendencias actuales que apelan a distintas excusas y justificaciones de las fallas morales, así como las explicaciones funcionales que pretenden desrealizar el peso de la responsabilidad individual, y los intentos de hacer desaparecer el agente moral. La teoría que concibe el mal como privación de ser o bondad, negando su realidad y estatuto ontológico positivo, se remonta a Platón (c. 427-347 a. C.), culmina con Leibniz (1646-1716) y persiste de otro modo en Kant y Hegel (1770-1831). Schelling (1775-1854) se niega a continuar en esa línea, considerando un deber reconocer la realidad del mal. Su distanciamiento produce una transformación en el modo de entender el problema, poniendo así término a la teodicea como justificación de y reconciliación con el mal.

Lévinas, por su parte, considera el mal como un "exceso en su esencia misma", dado que éste se resiste a las categorías de comprensión o razón. De ahí que el autor postule una trascendencia del mal, irreductible a una comprensión absoluta ${ }^{9}$.

Para Hans Jonas (1903-1993) y Lévinas, ambos marcados por su experiencia en Auschwitz, la tarea filosófica más urgente es indagar el sentido de la ética y la responsabilidad ante el mal del siglo XX. Según ellos, sólo los seres humanos son responsables del mal existente, y su deber es combatirlo.

Jonas, en particular, entiende dicha responsabilidad en relación con Dios: "de y para el Dios que sufre, que cambia, que se preocupa"10. Este modo de concebir la responsabilidad humana abre un horizonte relacional que cuestiona la omnipotencia y el carácter absoluto de Dios,

9 Emmanuel Lévinas. "Trascendencia y maldad". Citado por BERNSTEIN, op. cit., pp. 243-4.

10 BERNSTEIN, op. cit., p. 275. 
afirmados por la teodicea. El autor expresa dicho cuestionamiento en los siguientes términos:

Y quiero creer esto: que en las alturas se lloró ese desperdicio y esa rapiña de vidas humanas; que un gemido $-y$ luego la ira- fueron la respuesta al grito ascendente del sufrimiento infame, el terrible daño causado a la realidad y la posibilidad de cada vida perversamente victimizada, cada una de ellas un frustrado intento de Dios. (...) ¿No hemos de creer que el inmenso coro de lamentos que se alzó en nuestra época ahora pende sobre el mundo como una oscura y acusadora nube? ¿Que la eternidad nos mira con desprecio y desaprobación, ella misma malherida y alterada en sus profundidades? ${ }^{11}$

En 1945, Arendt, también marcada por su experiencia en relación con Auschwitz, sostuvo que el mal iba a ser el problema fundamental de la vida intelectual europea de postguerra. Según ella, en las etapas finales del totalitarismo, surge el mal absoluto, en el sentido de que es imposible derivarlo de motivos humanos comprensibles.

Conforme al entendimiento de Arendt, el mal radical tiene que ver con "hacer que los seres humanos en tanto seres humanos se vuelvan superfluos"12. Esto ocurre cuando se elimina la espontaneidad, entendida como la capacidad del ser humano para iniciar algo nuevo con sus propios recursos, de modo imprevisible. Bernstein observa correctamente que:

(...) los principales sucesos políticos del siglo XX, desde la Primera Guerra en adelante, han generado millones de personas que no sólo carecen de casa y de Estado, sino que además son tratadas como si fueran completamente superfluas y prescindibles.

11 Hans Jonas. "Inmortality and the Modern Temper", en Mortality and Morality. Citado por BERNSTEIN, op. cit., p. 275.

12 Hannah Arendt / Karl Jaspers. Correspondance. Citado por BERNSTEIN, op. cit., p. 288. 
Un ejemplo pasmoso de esto es el incendio acaecido en Valparaíso los días 12, 13 y 14 de abril de 2014, que abarcó más de tres kilómetros en lo alto de sus cerros, donde habita la mayoría de los pobres de la ciudad -en varios casos, sin agua potable, ni alcantarillado-, con consecuencias devastadoras, inenarrables, pero previsibles por parte de los agentes del Estado chileno y la empresa privada. Los efectos del incendio, que arrasó más de tres mil viviendas, arrojando quince muertos y miles de damnificados, han sido comparados con los de una bomba atómica.

Ahora bien, para Arendt, el término "mal radical" se refiere a "lo peculiar del mal de la dominación total"13. Su modelo son los campos de exterminio, entendidos como laboratorios de los regímenes totalitarios, en los que se buscaba alterar la naturaleza humana misma.

La autora distingue tres fases analíticas en dicho proceso de la dominación total: 1. Matar a la persona jurídica, despojando a los judíos y otros grupos marginales de sus derechos, antes de la instalación de los campos. 2. Matar a la persona moral en el ser humano. La SS encontró una forma eficaz de corromper toda forma de solidaridad, pervirtiendo las decisiones de conciencia de sus reclusos, despojados ya de todo derecho jurídico. Al obligarlos a enfrentarse al dilema de escoger, por ejemplo, a qué miembro de su familia matar primero, la alternativa impuesta por la SS no era ya entre el bien y el mal, sino entre un crimen y otro. Y 3. Transformar a los seres humanos, haciéndolos superfluos mediante la destrucción en ellos de toda forma de espontaneidad, individualidad y libertad. Para Arendt, éste es el núcleo y el horror del mal radical.

Ella sostiene que el totalitarismo puede prolongarse de otro modo, a través de fuertes tentaciones, allí donde parezca imposible aliviar la miseria en cualquiera de sus manifestaciones: política, social o económica. Pero también cabría pensar en una prolongación difusa de esas tres fases del proceso de la dominación total en sociedades neoliberales basadas en el hedonismo de la sociedad de consumo, cuyo funcionamiento supone un consenso masivo e indiferenciado, 
decantado como sentido común inmune a la crítica. Su naturalización se basa en la exclusión, la destrucción de la solidaridad y de la espontaneidad, la mezquindad organizada como norma, la desanimación, la muerte de los sentimientos, del alma y de toda forma de vida interior; el recurso a relaciones humanas utilitarias funcionales a la productividad, administración y reproducción del modelo de gestión en negocios, en todos los niveles, y la proliferación de seres considerados superfluos, sea que protesten o demuestren una disposición psíquica y una disponibilidad a ser transformados en cosas, en función de su mera sobrevivencia y a cualquier costo, para así potenciar la falsa ilusión de que se realizan como seres humanos, siempre ganadores. Éstos y otros rasgos perversos y abominables, caracterizan al Chile postdictatorial y su espíritu fascista. Y una de las muestras más terroríficas y extremas de las irradiaciones de dicho proceso de descomposición moral, social y espiritual, bajo la égida del neoliberalismo triunfante, ha sido el devastador y terminal incendio de Valparaíso.

\section{El mal, la muerte y el duelo inconcluso}

El gavilán se relaciona con estas cuestiones en aspectos como los siguientes. Esta obra presenta un crimen y un acto de maldad colectiva, con los que no busca reconciliarse. Al hacer explícito el sufrimiento de la víctima y su autoconciencia, a través de su relato post mortem acerca de cómo llega a ser asesinada por una comunidad que la considera superflua, en el sentido de desechable, sacrificable y sin derechos, Violeta reconoce el peso de la realidad del mal y de la maldad humana. La hablante expone su ruta hacia la muerte violenta, pero no la justifica, ni se place en ella. Tampoco Violeta. Muy por el contrario, que la hablante sea presentada como un alma en pena, muestra que esta obra tiene un final abierto, que su realización no ha concluido.

María Nieves Alonso analiza las Décimas en el marco de una investigación acerca de las formas y figuras de la muerte en la poesía chilena. La autora desarrolla relevantes intuiciones y asociaciones que vinculan 
la presencia de sucesivas muertes, en el curso de la biografía de Violeta, con asuntos como la vergüenza del sobreviviente, el trabajo del duelo y el mal absoluto. Este último se desprende de la experiencia de la muerte en situaciones límite. Mientras que el suicidio de Violeta aparece relacionado con la voluntad de poner término a un duelo inconcluso.

Corresponde destacar tres momentos en las reflexiones de Alonso, que abren otro horizonte de interrogantes acerca del significado del suicidio de Violeta, en relación con el problema del mal:

¿Qué intercambios se establecen entre la poeta sobreviviente y los espectros de los difuntos?

\section{$(\ldots)$}

Con esos espectros se bate Violeta Parra, ellos dan origen a la alternativa de vivir o escribir y no poder ya vivir... Para conjurar y exorcizar el horror hay que pasar pues por el trabajo de la memoria y el trabajo de duelo y, entonces, recién tal vez ser libre y elegir o pensar en el amor.

\section{$(\ldots)$}

Es que nos preguntamos si también los muertos siguen existiendo, sobre el coraje de afrontar la muerte a través de la escritura, sobre la tentación del suicidio. ¿La poeta se mató, como Primo Levi, porque quizás su plegaria no fue escuchada, porque no pudo dar simbólica sepultura a los espectros que la acompañaban desde la escena primordial? ${ }^{14}$

14 ALONSO, María Nieves. "La soberanía sobre la muerte: el caso de Violeta Parra", en Atenea $\mathrm{N}^{\circ}$ 504, $2^{\circ}$ semestre 2011, Universidad de Concepción. En www.scielo.cl. Pp. 13, 27 y 25. Primo Levi (1919-1987), químico y escritor judío italiano, resistente antifascista, sobreviviente del campo de concentración de Monowice, subalterno del de Auschwitz. 
Esto se hace patente a través de los siguientes versos de Violeta, extraídos de sus Décimas:

No lloro yo por llorar sino por hallar sosiego, mi llorar es como un ruego que naide quier' escuchar, del ver y considerar la triste calamidá' que vive l'humanidá' en toda su longitú'; l'escasez de la virtú' es lo que me hace llorar ${ }^{15}$.

Si bien las consideraciones de Alonso se refieren, en primer lugar, a la biografía de Violeta, éstas también pueden extenderse al contenido de El gavilán, con el cual se confunde por momentos, en lo que se refiere a la memoria, el duelo, la muerte y el suicidio como prefiguración de un mal colectivo. Al igual que el fantasma del rey Hamlet asesinado, la hablante post mortem de El gavilán también anuncia una catástrofe política: el golpe de Estado de 1973 y su posteridad. El fantasma de la mujer asesinada por la comunidad reconoce la maldad de que ha sido objeto. Por eso, habla desde el otro lado de la muerte, en busca de conciencia, verdad y justicia.

En el horizonte del problema del mal, El gavilán apunta al problema de la teodicea como justificación del mal, y la necesidad de reconocer sus límites históricos. La ruptura implicada en esta cuestión se desprende de la historia política del siglo XX. En particular, del nazismo y los campos de exterminio, de los que tanto la dictadura como la postdictadura en Chile son tributarias. Por otro lado, el reconocimiento de una trascendencia del mal, entendida como una realidad que se resiste a una comprensión absoluta, y vinculada al fin de la teodicea, se muestra a través de esa especie de excedente 
post mortem presente en El gavilán, que se desprende de la imagen de una voz que habla desde el otro lado de la muerte, desde un más allá imposible.

Por último, desde la perspectiva de Jonas, quien entiende la responsabilidad humana desde el Dios que sufre ante la maldad, El gavilán pudiera ser considerada como una manifestación de ese sufrimiento. La espontaneidad, en el sentido de Arendt, asociada al inaudito surgimiento de esta obra, como ruptura y continuidad con la tradición investigada por Violeta, es una brecha que se abre para mostrar el abismo no sólo del sufrimiento humano enfrentado a la dominación y la maldad, sino también del sufrimiento de Dios mismo ante ese horror $^{16}$. La conjunción de vida y obra que guió el destino de Violeta como encarnación del inconsciente colectivo chileno, su identificación con dicha tradición y con el sufrimiento que observó desde y por siempre, constituyen una base que permite pensar a la autora como canal de comunicación y manifestación de otras dimensiones de la realidad. Y una de ellas es el Dios que sufre, malherido y alterado en sus profundidades. Las imágenes sonoras y musicales predominan en las expresiones de Jonás: el llanto, los gemidos, la ira, el grito ascendente del sufrimiento infame, el inmenso coro de lamentos de esta época. Son elementos que también se desprenden de El gavilán y otras obras de Violeta, pero sobre todo de aquélla. Según Adela Gallo, la compuso en medio de una crisis que, de algún modo, involucraba a la comunidad. Si esto es verdad, tal vez en medio de ella alguna brecha se abrió, y Dios manifestó su voz quebrada por el espanto, a través del alma de Violeta.

\section{Devenir del problema del mal en Violeta}

En Cantores que reflexionan, incluida en sus Últimas composiciones (1966), Violeta se refiere a los cantores encarcelados en el Reino de

16 "Abrir brecha", en el sentido de "dar los primeros pasos en algo venciendo algún tipo de resistencia". Real Academia de la Lengua, Diccionario de la lengua española, vigésima segunda edición, 2001. 
Satán; esto es, atrapados por el poder del dinero, el placer, la vanidad, la traición, la oscuridad y la mentira, en oposición a la luz de la verdad. La hablante pide al sol, símbolo de la divinidad, que ayude al cantor encarcelado, iluminando el fondo de su ser, para que así la luz vuelva a brotar de su voz, y su conciencia cante al ser humano en su dolor, miseria y esfuerzos.

El concepto de una música, cuya composición e interpretación se relacionan íntimamente con el alma invisible del compositor o intérprete, se expresa a través de los siguientes versos, incluidos en "Reflexiones" (ca. 1943):

No creas tú que yo ignoro

Lo que vale una sonata

Tu música puede ser

Más pura que las cascadas

Pero quien la está tocando

Tiene turbia la mirada $(. . .)^{17}$.

Dicho concepto corresponde al que se desprende de Cantores que reflexionan. Pero también, por contraste, a la conexión que la machi establece tanto con sus cantos como con sus instrumentos, durante los rituales. En "Reflexiones", Violeta alude lúcidamente a una disociación encubierta por las apariencias o por una percepción superficial, vinculada de algún modo con la oscuridad, la mentira y la maldad. El proverbio chino que sentencia: "Si el hombre erróneo usa el medio correcto, el medio correcto actúa erróneamente", ilustra con precisión la relación entre el alma y la acción e instrumentos usados por el ser humano, en cualquier orden de $\operatorname{cosas}^{18}$.

17 "Reflexiones". Manuscrito de Violeta Parra entregado a Margarita Montenegro, ca. 1943. En PARRA, Isabel. El Libro Mayor de Violeta Parra. Un relato biográfico y testimonial, Cuarto Propio, Santiago de Chile, 2009. Pp. 164-5.

18 Proverbio chino, citado por Jung, en "Comentario al libro El secreto de la Flor de Oro" (1929), en JUNG, C. G. / WILHELM, Richard. El secreto de la Flor de Oro, Paidós, Barcelona, 1961. P. 25. 
En Cantores que reflexionan, sus "Reflexiones", y Una copla me ha cantado, Violeta alude a ese fondo siniestro, maligno y sin nombre, capaz de apoderarse del alma del intérprete o del compositor desde dentro, y pervertir su música, ya sea a través de su entrega al espíritu del mundo, en el caso de la primera; de una disociación entre la interpretación musical o la composición, y su alma inconsciente, en el caso de la segunda; o de una abierta intención de destruir y matar, en el caso de la tercera. Sus "Reflexiones" demuestran que Violeta venía percibiendo o intuyendo la acción de ese fondo siniestro desde su juventud. Y es probable que sus observaciones hayan determinado su búsqueda posterior, como lo muestran los otros ejemplos comentados. Cantores que reflexionan alude al conflicto interno del músico, psicológico, moral y político, frente al mal dentro de sí mismo, expresado como alienación y pérdida de la capacidad reflexiva, desde y acerca del sentido de su actividad en el mundo. Y por último, en Una copla me ha cantado, esa potencia maligna aparece intensificada como acción vinculada, tal vez, a alguna forma de magia negra, en vistas a su eficiencia, y cuya intención es abiertamente destruir y matar.

Ahora bien, la culminación de esta línea, en el pensamiento de Violeta, es El gavilán. Su contenido se refiere a una persecución seguida de homicidio. Mientras que su forma se refiere a su estructura oculta: un sacrificio cruento al Diablo, también como parte de un rito de magia negra.

Es pertinente insistir aquí en la distinción entre forma y contenido, por un lado, y la acción misma de componer esta pieza, por otro. El gavilán es una obra acerca del mal. Pero ella no es, en sí misma, una extensión del mal, ni su composición e interpretación son parte de un rito de magia negra. Tanto su forma y contenido, como el asunto y la composición de esta obra, constituyen conjunciones de opuestos. A través de éstas, Violeta elabora un símbolo, en vistas a exorcizar el mal, haciéndolo consciente en todo su horror.

Acaso haya sido ésta la finalidad más alta e integral de su vida y obra: luchar contra el mal no sólo en su presente, sino también prospectivamente, a través de la ampliación de la conciencia y el conocimiento que el examen de aquéllas posibilita. Dicho examen muestra la plasmación de elementos musicales, poéticos, reflexivos y espirituales, 
para exorcizar la magia negra estructural total que domina y conduce a Chile, desde la transversalidad del lumpenfascismo y su lengua del Infierno, en una rapiña transgeneracional, asimilada y reproducida a gran escala ${ }^{19}$.

Esa lucha sostenida en el tiempo también se desprende de sus Décimas, en las cuales se refiere a las motivaciones y sentido de su poesía, como trasfondo y definición unitaria de su experiencia, pensamiento y actividad:

Si escribo esta podesía no es sólo por darme gusto más bien por meterle un susto al mal con alevosía; quiero marcar la partía, por eso prendo centella, que me ayuden las estrellas con su inmensa claridad pa' publicar la verdad que and'a la sombra en la tierra ${ }^{20}$.

Violeta se refiere a un mal tan absoluto como relacional y humano. Por un lado, la cuestión de la trascendencia del mal, que apunta a su carácter absoluto, pero que se expresa a través de la hablante post mortem de EI gavilán, permanece abierta. Por otro, su obra plasma una concepción histórico-política del mal y lo demoníaco, a través de la pugna entre el amor y el poder, como prefiguración de la catástrofe chilena.

El problema del mal cuenta con diferentes enfoques, niveles y matices, como lo muestra Enrique Galán Santamaría ${ }^{21}$. El autor distingue entre los discursos acerca del mal, y las vivencias del mal experimentadas

\footnotetext{
19 Sobre el lumpenfascismo, véase OPORTO VALENCIA, Lucy. “La maduración de la serpiente. El Quiltro, el Movimiento Estudiantil y la putrefacción de Chile", en Cisma $N^{\circ} 1,2^{\circ}$ semestre 2011. Revista del Centro Telúrico de Investigaciones Teóricas (CTIT). www.cisma.ctit.cl.

20 PARRA, Violeta; op. cit, p. 158.

21 GALÁN SANTAMARÍA, Enrique. "Las funciones del mal". Texto inédito. Madrid, noviembre 2009.
} 
como hechos. Los primeros se encuentran en religiones, filosofías, artes y otros ámbitos del saber y el pensamiento, y se refieren a la "objetividad intersubjetiva del mal". Mientras que los segundos son parte de la psique de individuos, grupos y culturas, y se refieren a la "subjetividad individual" del mal.

La trascendencia del mal absoluto es irreductible a la comprensión humana. El sufrimiento inútil, e impune en la mayoría de los casos, vinculado a los crímenes contra la humanidad-como la tortura y la desaparición forzada de personas, entre otros-, y sus secuelas espirituales, psicológicas y sociales, hacen patente ese excedente irreductible. De ahí que una propuesta de resolución mediante la conciliación de opuestos, sin más, sea altamente problemática y dudosa, debido a la negación de la realidad que su aplicación mecánica implica. No obstante, en el plano de la subjetividad individual del mal, y el penoso proceso de reconocimiento, elaboración e integración de la sombra, en términos junguianos, la psicoterapia busca morigerar los perniciosos efectos de su proyección, e incluso "conseguir un bien a partir de ese mal", en algunos casos. Según Galán:

Un bien que se llama libertad interior, esto es, autoconsciencia y autodominio o, al menos, autocontención, cuyos males correspondientes, tan ampliamente repartidos en la cruda realidad, se llaman inconsciencia, dominación y desmesura ${ }^{22}$.

Esta conclusión apunta a la responsabilidad personal e individual, frente al mal padecido y provocado, cuyas consecuencias se expanden y ramifican colectivamente desde las oscuridades del alma, con efectos duraderos. La obra de Violeta contiene elementos para una fenomenología del mal, arraigada en imágenes arcaicas y conceptos metafísicos vinculados a problemáticas universales y arquetípicas, como el amor y el poder, la unidad y la disolución, la vida y la muerte, la justicia y la impunidad, la verdad y la mentira, entre otros. Asimismo, contiene elementos que apuntan a una epistemología. Esto es, un modo de 
entender el conocimiento, desde la conjunción entre el amor y la inteligencia, y la reflexión como forma de lucha contra las potencias destructoras de la conciencia, el alma y el espíritu, en todo su horror inenarrable, que son, precisamente, la inconsciencia, la dominación y la desmesura, cuya magnitud excluye obligatoriamente la superficialidad, el negacionismo y el facilismo en busca de soluciones prácticas, funcionales al hedonismo de la sociedad de consumo.

De ahí, por otro lado que, frente a las desrealizaciones y disoluciones postmodernistas, y sus intereses corporativos endogámicos, se imponga la necesidad de volver a una filosofía dura, pero ahora no sólo desarrollada sobre la base de conceptos y argumentos, sino también incorporando los hechos desde otras facetas de la condición humana, como la historia, la imaginación y la afectividad, entre otras. La filosofía debe hacerse cargo de los duros hechos de la realidad-traumática per se, en su insondable profundidad-y su verdad deslumbrante, abismal y mortal, cuya concienciación Violeta plasmó en su obra irradiante, para el autoconocimiento, la lucha y el despliegue de la dimensión política de la vida interior, incluso a costa de ella misma.

Valparaíso, agosto 2013 / abril-junio 2014

\section{Bibliografía}

AGOSIN, Marjorie / DÖLZ-BLACKBRUN, Inés. Violeta Parra: santa de pura greda. Un estudio sobre su obra poética, Planeta, Santiago de Chile, 1988.

ALONSO, María Nieves. "La soberanía sobre la muerte: el caso de Violeta Parra", en Atenea $N^{\circ}$ 504, $2^{\circ}$ semestre 2011, Universidad de Concepción. En www.scielo.cl.

BERNSTEIN, Richard. El mal radical. Una indagación filosófica (2002), LILMOD, Buenos Aires, 2005.

Biblia de Jerusalén. Desclée de Brouwer, Bilbao, 1975.

"Existenciales nocturnos. José Saavedra", en El espíritu de la época $\mathrm{N}^{\circ} 10$, Santiago de Chile, septiembre 1988.

GALÁN SANTAMARÍA, Enrique. "Las funciones del mal". Texto inédito. Madrid, noviembre 2009. 
JUNG, C. G. / WILHELM, Richard. El secreto de la Flor de Oro, Paidós, BarceIona, 1961.

MONTEALEGRE, Jorge. Violeta Parra. Instantes fecundos, visiones, retazos de memoria, Editorial Universidad de Santiago de Chile, 2011.

OPORTO VALENCIA, Lucy. El Diablo en la música. La muerte del amor en El gavilán, de Violeta Parra. $1^{\text {a }}$ edición, por Altazor, Viña del Mar, noviembre 2008. $2^{a}$ edición, corregida y aumentada, por Editorial Universidad de Santiago de Chile, octubre 2013.

"El homicidio fundador y la transición a la democracia en Chile: René Girard y el mecanismo del chivo expiatorio", en Causas perdidas. Ensayos de filosofía jurídica, política y moral, editado por M. E. Orellana Benado, Catalonia, Santiago de Chile, diciembre 2010.

"La maduración de la serpiente. El Quiltro, el Movimiento Estudiantil y la putrefacción de Chile" en Cisma No 1, $2^{\circ}$ semestre 2011. Revista del Centro Telúrico de Investigaciones Teóricas (CTIT). www.cisma.ctit.cl.

Una arqueología del alma. Ciencia, metafísica y religión en Carl Gustav Jung, Editorial Universidad de Santiago de Chile, octubre 2012.

ORELLANA BENADO, M. E. Prójimos lejanos. Ensayos de filosofía en la tradición analítica, Ediciones Universidad Diego Portales, 2011.

"Tradiciones y concepciones en filosofía", en Filosofía de la Filosofía, editado por Óscar Nudler, Enciclopedia Iberoamericana de Filosofía, vol. N³1, Trotta, Madrid, 2010.

PARRA, Isabel. El Libro Mayor de Violeta Parra. Un relato biográfico y testimonial, Cuarto Propio, Santiago de Chile, 2009.

PARRA, Violeta. Décimas. Autobiografía en verso (1970), Sudamericana, Santiago de Chile, 1999.

Real Academia de la Lengua. Diccionario de la lengua española, vigésima segunda edición, 2001. 